\title{
Predictors of mother and child DNA yields in buccal cell samples collected in pediatric cancer epidemiologic studies: a report from the Children's Oncology group
}

\author{
Jenny N Poynter ${ }^{1,2,3^{*}}$, Julie A Ross ${ }^{1,2}$, Anthony J Hooten ${ }^{2}$, Erica Langer ${ }^{2}$, Crystal Blommer ${ }^{2}$ and Logan G Spector ${ }^{1,2}$
}

\begin{abstract}
Background: Collection of high-quality DNA is essential for molecular epidemiology studies. Methods have been evaluated for optimal DNA collection in studies of adults; however, DNA collection in young children poses additional challenges. Here, we have evaluated predictors of DNA quantity in buccal cells collected for population-based studies of infant leukemia ( $N=489$ mothers and 392 children) and hepatoblastoma ( $H B ; N=446$ mothers and 412 children) conducted through the Children's Oncology Group. DNA samples were collected by mail using mouthwash (for mothers and some children) and buccal brush (for children) collection kits and quantified using quantitative real-time PCR. Multivariable linear regression models were used to identify predictors of DNA yield.
\end{abstract}

Results: Median DNA yield was higher for mothers in both studies compared with their children (14 $\mu \mathrm{g} \mathrm{vs.}<1 \mu \mathrm{g}$ ). Significant predictors of DNA yield in children included case-control status ( $\beta=-0.69,50 \%$ reduction, $P=0.01$ for case vs. control children), brush collection type, and season of sample collection. Demographic factors were not strong predictors of DNA yield in mothers or children in this analysis.

Conclusions: The association with seasonality suggests that conditions during transport may influence DNA yield. The low yields observed in most children in these studies highlight the importance of developing alternative methods for DNA collection in younger age groups.

Keywords: DNA collection, Buccal cells, Pediatric epidemiology

\section{Background}

Biological samples are frequently collected in epidemiologic studies to evaluate genetic susceptibility to disease. Blood samples provide a large quantity of high quality DNA; however, collection of blood is invasive, expensive and typically not feasible in studies covering a large geographic area. Importantly, the use of non-invasive DNA collection methods has been shown to increase study participation rates [1]. Buccal and saliva samples are a non-invasive and inexpensive way to collect DNA in population-based studies, which, in turn, has been

\footnotetext{
* Correspondence: poynt006@umn.edu

'Division of Epidemiology and Clinical Research, Department of Pediatrics, University of Minnesota, Minneapolis, MN, USA

${ }^{2}$ Masonic Cancer Center, University of Minnesota, Minneapolis, MN, USA Full list of author information is available at the end of the article
}

successfully evaluated using high-throughput genotyping methods [2-4].

Genetic variants are especially likely to be relevant in pediatric diseases such as cancer due to the early age of onset;[5,6] however, collection of DNA from infants and young children poses significant challenges [7-11]. While blood samples resulted in higher DNA yields, $[7,9]$ data suggest that buccal cell samples from children also provide sufficient DNA for genotyping for a limited number of loci [7,9-11]. Studies comparing different methods of buccal cell collection have indicated that treated cards, specifically FTA Micro cards, may result in better genotyping results than buccal swab samples, although other complexities, including difficulty processing the samples, were noted $[10,11]$. These studies have also suggested that whole genome amplification (WGA) can be successfully

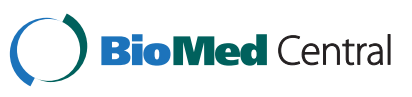


used to increase DNA yields in buccal cells collected from children $[7,11]$. In adult studies, mouthwash collection of buccal cells and collection of saliva samples using commercial kits have shown increased DNA yields [12-15]; however, these methods are not feasible for young children.

In this analysis, we evaluated predictors of DNA quantity in mothers and children from buccal samples collected for population-based studies of infant leukemia and hepatoblastoma $(\mathrm{HB})$ conducted through the Children's Oncology Group (COG).

\section{Results}

\section{Characteristics of the study population}

DNA samples were available for 427 children and 462 mothers in the HB study, and 396 children and 494 mothers in the infant leukemia study. Mothers and children with missing maternal interview data were excluded from the analyses $(\mathrm{N}=15 \mathrm{HB}$ children and mothers, 4 infant leukemia children and 5 infant leukemia mothers). Selected characteristics of children and mothers with DNA and interview data are shown in Table 1.

Approximately half of the children in both studies were under age 5 years at the time of DNA collection. Approximately $60 \%$ of the DNA samples were from cases in both studies. DNA extraction was initiated within one week of receipt of DNA for the majority of samples. There was no correlation between DNA yield in mother and child pairs $(\mathrm{r}=-0.006, P=0.86)$. As expected, DNA yield was significantly higher in mothers than children $(\mathrm{t}$ Value two-sample $t$-test with unequal variance $=34.85$, $\mathrm{p}<0.0001)$. The yield was much higher for the 35 children in the HB study who were old enough to provide DNA by mouthwash collection (median $6.5 \mu \mathrm{g}$, range $0-$ $139 \mu \mathrm{g})$ compared to the children who provided DNA by buccal brush collection (median $0.26 \mu \mathrm{g}$, range $0-12 \mu \mathrm{g}$ ).

\section{Predictors of DNA yield in children}

Results from multivariable linear regression models evaluating predictors of DNA yield are shown in Table 2. Models were adjusted for all covariates included in the table. Duration of storage in the laboratory prior to DNA extraction and maternal education were also evaluated; however, these variables were not confounders and were not included in the final models. In children from the HB study, significantly lower DNA yields were obtained for cases than controls, children whose mother reported race other than white, and for samples received during the summer months. In addition, samples collected using the Epicentre brush or mouthwash yielded significantly higher amounts of DNA than samples collected with the Cytosoft brush. Similar results for case control status, brush type and season of DNA collection were observed in the infant leukemia study, although the results for case-control status did not reach statistical significance. In the analysis of children from both study populations, significant associations were observed for case-control status, sample collection type, and season of DNA collection. DNA yields were significantly higher for children in the HB study than for children in the infant leukemia study. Because of the large difference in DNA yield by sample collection type, we repeated the analysis after excluding the 35 children in the HB study who provided DNA through mouthwash collection. The results of the analysis were unchanged when these individuals were removed.

We also evaluated season of DNA collection separately for each DNA collection method. In a combined analysis of all children, we found a significant difference for seasonality of DNA collection for samples collected with the Cyto-Pak Cytosoft brushes $(\beta=-2.95, P<0.0001$ for summer vs. spring) but not for samples collected with the Epicentre Catch-All Sample Collection swabs $(\beta=-0.80$, $\mathrm{p}=0.09$ for summer vs. spring) or for the mouthwash samples $(\beta=-0.33, P=0.63$ for summer vs. spring).

\section{Predictors of DNA yield in mothers}

No significant predictors of DNA yield were identified in mothers in the HB study (Table 3 ). In mothers from the infant leukemia study, associations were observed for the mother's age at DNA collection, case control status of her child, and season of DNA collection. In the combined model, mothers over age 40 years at DNA collection had significantly lower DNA yield than mothers younger than 30 . Samples received in the fall and winter had higher yields than samples received in the spring. This is in contrast to the findings in the children, where yields were significantly lower in samples collected in the fall and there was no significant difference between samples collected in the spring and winter (Table 2).

\section{Discussion}

In this analysis of DNA yield from buccal cells collected in two population-based case-control studies of childhood cancer, we identified several predictors of DNA yield including case-control status of the child and season of DNA collection. The samples collected from cases in both studies had a significantly lower DNA yield compared with samples from controls. The child samples also had a lower yield if they were collected in the summer months compared with the spring, which was consistent across both study populations.

Studies in adults have reported higher DNA yields from mouthwash samples compared with buccal brush samples [12,16-18]. In this analysis, we also found that this method yielded higher amounts of DNA in children who were old enough to provide a mouthwash sample. Proposed explanations for the higher yield associated 
Table 1 Selected characteristics of the study population

\begin{tabular}{|c|c|c|}
\hline Characteristic & $\begin{array}{c}\text { HB study } \\
\text { N (\%) }\end{array}$ & $\begin{array}{c}\text { Infant leukemia study } \\
N(\%)\end{array}$ \\
\hline $\mathrm{N}$ children with samples & 412 & 392 \\
\hline Median DNA yield $(\mu \mathrm{g})$ & $0.37(0-139)$ & $0.15(0-14)$ \\
\hline \multicolumn{3}{|c|}{ Child's age at DNA collection } \\
\hline $0-2$ years & $45(11)$ & $75(19)$ \\
\hline $2-5$ years & $151(37)$ & $123(31)$ \\
\hline$>5$ years & $216(52)$ & $194(49)$ \\
\hline \multicolumn{3}{|l|}{ Child's sex } \\
\hline Male & $241(58)$ & $183(47)$ \\
\hline Female & $171(42)$ & $209(53)$ \\
\hline \multicolumn{3}{|l|}{ Case control status } \\
\hline Case & $246(60)$ & $223(57)$ \\
\hline Control & $166(40)$ & $169(43)$ \\
\hline \multicolumn{3}{|l|}{ Storage (Child's sample) } \\
\hline $0-3$ days & $108(29)$ & $121(46)$ \\
\hline $3-7$ days & $99(26)$ & $64(24)$ \\
\hline 7 - 14 days & $92(24)$ & $54(21)$ \\
\hline$>14$ days & $79(21)$ & $23(9)$ \\
\hline \multicolumn{3}{|l|}{ Season of DNA collection } \\
\hline Spring & $119(29)$ & $117(30)$ \\
\hline Summer & $117(28)$ & $80(20)$ \\
\hline Fall & $90(22)$ & $109(28)$ \\
\hline Winter & $86(21)$ & $86(22)$ \\
\hline \multicolumn{3}{|l|}{ Sample collection } \\
\hline Cytosoft brush & $175(42)$ & $341(87)$ \\
\hline Epicentre brush & $202(49)$ & $51(13)$ \\
\hline Mouthwash & $35(9)$ & \\
\hline N Mothers with samples & 446 & 489 \\
\hline Median DNA yield $(\mu \mathrm{g})$ & $14(0.02-401)$ & $14(0.06-1209)$ \\
\hline \multicolumn{3}{|c|}{ Mother's age at DNA collection } \\
\hline$<30$ years & $89(20)$ & $104(21)$ \\
\hline $30-35$ years & $117(26)$ & $147(30)$ \\
\hline $35-40$ years & $131(29)$ & $134(27)$ \\
\hline$>40$ years & $109(24)$ & $104(21)$ \\
\hline \multicolumn{3}{|l|}{ Storage (Mother's sample) ${ }^{a}$} \\
\hline $0-3$ days & $110(27)$ & $121(38)$ \\
\hline $3-7$ days & $126(31)$ & $104(33)$ \\
\hline 7 - 14 days & $100(25)$ & $57(18)$ \\
\hline$>14$ days & $68(17)$ & $35(11)$ \\
\hline \multicolumn{3}{|l|}{ Maternal education } \\
\hline$<$ High School & $31(7)$ & $26(5)$ \\
\hline High School & $74(17)$ & $104(21)$ \\
\hline Some college & $115(26)$ & $146(30)$ \\
\hline College degree & $158(35)$ & $152(31)$ \\
\hline
\end{tabular}

Table 1 Selected characteristics of the study population (Continued)

\begin{tabular}{|c|c|c|}
\hline Advanced degree & $68(15)$ & $61(13)$ \\
\hline \multicolumn{3}{|l|}{ Maternal race } \\
\hline White & $349(78)$ & $411(84)$ \\
\hline Black & $18(4)$ & $19(4)$ \\
\hline Hispanic & $50(11)$ & $30(6)$ \\
\hline Asian & $18(4)$ & $16(3)$ \\
\hline Other & $11(2)$ & $13(3)$ \\
\hline \multicolumn{3}{|l|}{ Income } \\
\hline$<\$ 20,000$ & $65(15)$ & $73(15)$ \\
\hline$\$ 20,000--\$ 50,000$ & $122(28)$ & $183(38)$ \\
\hline$\$ 50,000--\$ 75,000$ & $102(23)$ & $110(23)$ \\
\hline$>\% 75,000$ & $153(35)$ & $122(25)$ \\
\hline \multicolumn{3}{|c|}{ Season of DNA collection } \\
\hline Spring & $128(29)$ & $138(28)$ \\
\hline Summer & $126(28)$ & $100(20)$ \\
\hline Fall & $98(22)$ & $140(29)$ \\
\hline Winter & $94(21)$ & $111(23)$ \\
\hline
\end{tabular}

with mouthwash collection include inhibition of bacterial growth in the sample during transport and storage due to the alcohol content of the mouthwash [16] and reduced DNA degradation in the mouthwash samples during collection and mailing at room temperature [12]. This well-documented increased yield indicates that this method may be ideal for collecting DNA in older children; however, this method is not suitable for use in very small children.

We observed a significantly lower DNA yield in samples collected from children during the summer months. This difference was observed only in the child samples, and the magnitude of this difference was larger in the infant leukemia study compared with the HB study. This finding can be attributed to differences in DNA collection by age group and study as this finding was limited to the Cyto-Pak Cytosoft brushes, which were used only in children and in a higher proportion of children in the infant leukemia study. To our knowledge, this effect of seasonality has not been reported previously; one potential explanation is DNA degradation caused by increased bacterial growth at higher temperatures. In a recent study of DNA collected for a study of infants, Gallagher et al. [19] reported higher DNA yield and quality in cytobrush samples that were allowed to air dry compared with samples collected by standard collection methods (i.e. storage in a plastic tube) presumably due to reduced 
Table 2 Predictors of DNA Yield (log_e transformed) in children

\begin{tabular}{|c|c|c|c|c|c|c|c|c|c|}
\hline & \multicolumn{3}{|c|}{$H B(N=412)$} & \multicolumn{3}{|c|}{ Infant Leukemia $(N=392)$} & \multicolumn{3}{|c|}{ Combined $(N=804)$} \\
\hline & $\beta^{\mathrm{a}}(95 \% \mathrm{Cl})$ & $\%$ change $^{b}$ & $P$ value & $\beta^{\mathrm{a}}$ & $\%$ change $^{b}$ & $P$ value & $\beta^{a}$ & $\%$ change $^{\mathbf{b}}$ & $P$ value \\
\hline \multicolumn{10}{|c|}{ Age at DNA collection (years) } \\
\hline $0-2$ & $0.60(-0.27-1.47)$ & 81 & 0.18 & $0.81(-0.37-1.99)$ & 125 & 0.18 & $0.67(-0.09-1.42)$ & 95 & 0.08 \\
\hline $2-5$ & $-0.10(-0.65-0.46)$ & -9.1 & 0.74 & $-0.76(-1.72-0.20)$ & -53 & 0.12 & $-0.42(-0.97-0.12)$ & -34 & 0.13 \\
\hline$>5$ years & Reference & Reference & & Reference & Reference & & Reference & Reference & \\
\hline \multicolumn{10}{|l|}{ Child's sex } \\
\hline Male & Reference & Reference & & Reference & Reference & & Reference & Reference & \\
\hline Female & $0.06(-0.42-0.55)$ & 6.6 & 0.80 & $0.47(-0.35-1.28)$ & 60 & 0.26 & $0.31(-0.17-0.78)$ & 36 & 0.21 \\
\hline \multicolumn{10}{|l|}{ Study } \\
\hline $\mathrm{HB}$ & NA & NA & NA & NA & NA & NA & Reference & Reference & \\
\hline Infant leukemia & NA & NA & NA & NA & NA & NA & $-1.05(-1.60--0.51)$ & -65 & 0.0002 \\
\hline \multicolumn{10}{|c|}{ Case control status } \\
\hline Control & Reference & Reference & & Reference & Reference & & Reference & Reference & \\
\hline Case & $-0.65(-1.18--0.11)$ & -48 & 0.01 & $-0.64(-1.52-0.25)$ & -42 & 0.16 & $-0.69(-1.20--0.17)$ & -50 & 0.01 \\
\hline \multicolumn{10}{|l|}{ Collection type } \\
\hline Cytosoft brush & Reference & Reference & & Reference & Reference & & Reference & Reference & \\
\hline Epicentre brush & $0.94(0.43-1.45)$ & 160 & 0.0003 & $2.46(1.15-3.76)$ & 1070 & 0.0002 & $1.23(0.64-1.81)$ & 242 & $<0.0001$ \\
\hline Mouthwash & $4.22(3.26-5.17)$ & 6670 & $<0.0001$ & NA & & NA & $4.42(3.16-5.67)$ & 8210 & $<0.0001$ \\
\hline \multicolumn{10}{|l|}{ Maternal race } \\
\hline White & Reference & Reference & & Reference & Reference & & Reference & Reference & \\
\hline Other & $-0.66(-1.24--0.08)$ & -49 & 0.03 & $0.36(-0.75-1.47)$ & 43 & 0.52 & $-0.19(-0.80-0.42)$ & -17 & 0.52 \\
\hline \multicolumn{10}{|c|}{ Season of DNA collection } \\
\hline Spring & Reference & Reference & & Reference & Reference & & Reference & Reference & \\
\hline Summer & $-0.89(-1.52--0.26)$ & -59 & 0.006 & $-3.85(-5.03--2.66)$ & -97 & $<0.0001$ & $-2.06(-2.71--1.42)$ & -87 & $<0.0001$ \\
\hline Fall & $-0.36(-1.05-0.33)$ & -30 & 0.31 & $-1.56(-2.67--0.45)$ & -79 & 0.006 & $-0.84(-1.50--0.19)$ & -57 & 0.01 \\
\hline Winter & $0.01(-0.67-0.70)$ & 1.5 & 0.97 & $1.02(-0.13-2.17)$ & 469 & 0.08 & $0.54(-0.13-1.22)$ & 72 & 0.11 \\
\hline
\end{tabular}

${ }^{a}$ Models were adjusted for all other variables in table.

b Percent change in DNA yield compared to referent.

bacterial growth in samples not stored in humid conditions. If confirmed in additional studies, a drying procedure may increase feasibility in pediatric populations where DNA collection is difficult.

In our study, DNA samples from cases yielded a significantly lower quantity of DNA compared with samples from controls. This finding is in contradiction to an Australian study of children with acute lymphoblastic leukemia where median DNA yield was higher in 31 cases compared to 52 control children [10]. However, DNA collection was completed in a clinic setting for a proportion of the cases, where participant adherence to instructions could be monitored, so this could at least partially explain this discrepant finding. The explanation for the lower yield of DNA in cases compared with controls is not obvious. One potential explanation is the possibility that mothers used less vigorous swabbing in the cases due to oral sensitivity following chemotherapy. Alternatively, technical variation (i.e. a hidden batch effect) confounded by case-control status could also explain the finding.

Demographic variables within the mother and child subgroups were not strong predictors of DNA yield. Within the samples collected by buccal brush, there were no differences in DNA yield by age group. In previous studies, DNA yield was higher for males than females $[20,21]$; however, we did not observe such a difference in either pediatric population. Previous studies have reported lower DNA yield in individuals of non-white race [21]. While we observed a lower DNA yield in the HB study for children where the mother reported non-white race, no difference was observed in the infant leukemia study nor in the mothers in either study. As the majority of both study populations was white, we had limited power to detect racial differences in DNA yield.

This study measured DNA yield; however, the real parameter of interest is the ability to successfully conduct 
Table 3 Predictors of DNA Yield (log_e transformed) in mothers

\begin{tabular}{|c|c|c|c|c|c|c|c|c|c|}
\hline & \multicolumn{3}{|c|}{$H B(N=446)$} & \multicolumn{3}{|c|}{ Infant leukemia $(N=489)$} & \multicolumn{3}{|c|}{ Combined $(N=935)$} \\
\hline & $\beta^{a}$ & $\%$ change $^{b}$ & $P$ value & $\beta^{a}$ & $\%$ change $^{b}$ & $P$ value & $\beta^{a}$ & $\%$ change $^{b}$ & $P$ value \\
\hline \multicolumn{10}{|c|}{ Age at DNA collection (years) } \\
\hline$<30$ years & Reference & Reference & & Reference & Reference & & Reference & Reference & \\
\hline $30-35$ years & $0.06(-0.35-0.47)$ & 6.2 & 0.78 & $-0.25(-0.67-0.16)$ & -22 & 0.23 & $-0.11(-0.41-0.18)$ & -10 & 0.45 \\
\hline $35-40$ years & $-0.16(-0.56-0.24)$ & -15 & 0.43 & $0.04(-0.39-0.46)$ & 4.1 & 0.86 & $-0.09(-0.38-0.21)$ & -8.6 & 0.57 \\
\hline$>40$ years & $-0.21(-0.62-0.21)$ & -19 & 0.33 & $-0.47(-0.93--0.01)$ & -37 & 0.04 & $-0.37(-0.68--0.05)$ & -31 & 0.02 \\
\hline \multicolumn{10}{|l|}{ Study } \\
\hline$H B$ & NA & NA & NA & NA & NA & NA & Reference & Reference & \\
\hline Infant leukemia & NA & NA & NA & NA & NA & NA & $0.05(-0.15-0.26)$ & 5.1 & 0.63 \\
\hline \multicolumn{10}{|c|}{ Case control status } \\
\hline Control & Reference & Reference & & Reference & Reference & & Reference & Reference & \\
\hline Case & $-0.13(-0.41-0.16)$ & -12 & 0.38 & $0.41(0.09-0.72)$ & 51 & 0.01 & $0.14(-0.08-0.36)$ & 15 & 0.21 \\
\hline \multicolumn{10}{|l|}{ Maternal race } \\
\hline White & Reference & Reference & & Reference & Reference & & Reference & Reference & \\
\hline Other & $0.10(-0.23-0.44)$ & 11 & 0.54 & $0.13(-0.27-0.53)$ & 14 & 0.53 & $0.13(-0.14-0.39)$ & 14 & 0.34 \\
\hline \multicolumn{10}{|c|}{ Season of DNA collection } \\
\hline Spring & Reference & Reference & & Reference & Reference & & Reference & Reference & \\
\hline Summer & $0(-0.37-0.37)$ & 0 & 1.00 & $0.30(-0.12-0.73)$ & 35 & 0.16 & $0.18(-0.10-0.46)$ & 20 & 0.20 \\
\hline Fall & $-0.19(-0.57-0.20)$ & -18 & 0.35 & $0.82(0.43-1.21)$ & 127 & $<0.0001$ & $0.39(0.11-0.66)$ & 48 & 0.007 \\
\hline Winter & $0.25(-0.15-0.65)$ & 28 & 0.22 & $0.46(0.04-0.87)$ & 58 & 0.03 & $0.35(0.06-0.64)$ & 42 & 0.02 \\
\hline
\end{tabular}

${ }^{a}$ Models were adjusted for all other variables in table.

${ }^{b}$ Percent change in DNA yield relative to referent.

genotyping assays on the resulting DNA. SNP genotyping at a limited number of loci has been conducted in samples from both of the study populations. In a recent study evaluating four SNPs in the infant leukemia study, genotyping was successful for $171 / 189$ (90\%) samples included [22]. Similarly, the majority of the cases in the HB study were also successfully genotyped using the Sequenom platform (343/386 with complete triad data, $88 \%$ success rate; Spector el al. unpublished data). For more extensive genotyping applications, such as GWAS, the number of cases with sufficient DNA is more limited. For example, only $31 \%$ of cases in the HB study and $21 \%$ of cases in the infant leukemia study have a total DNA yield greater than or equal to $1 \mu \mathrm{g}$.

There are a number of strengths associated with this evaluation, including the population based data collection for both children and adults. In addition, DNA quantity was measured using $\mathrm{qPCR}$ and therefore provides an accurate measure of human DNA quantity. The availability of systematically measured covariates is also a strength. Several limitations must also be considered, including the limited number of mouthwash DNA samples in the pediatric age group, the lack of inclusion of fathers for comparisons, and the largely white study population. We also were not able to evaluate more recently developed DNA collection methods, such as Oragene saliva collection kits (DNA Genotek, Ontario, CA) that have been shown to yield suitable quantities of DNA in children [23].

\section{Conclusions}

As the focus of epidemiology studies becomes increasingly molecular, collection of DNA samples using cost-effective, reliable, and non-invasive methods is important. The low yields observed in most children in these studies indicate that buccal brush collection is not an ideal method for DNA collection in small children and that development of alternative methods is warranted.

\section{Methods}

\section{Infant leukemia study}

Detailed information regarding case and control ascertainment for the infant leukemia study has been described [24]. Briefly, cases were eligible for the study if they were diagnosed with acute lymphoblastic leukemia or acute myeloid leukemia prior to one year of age at a participating COG institution, did not have a diagnosis of Down syndrome, and had an English or Spanish speaking mother who was available for a telephone interview. Cases were recruited in two phases: 1) January 1, 1996 - October 13, 2002 and 2) January 1, 2003 - December 31, 2006.

Controls were also recruited in two phases corresponding to the time period for case ascertainment. Controls 
in Phase 1 were recruited using random digit dialing (RDD) using a modification of the methods of Waksberg [25]. Controls in Phase 2 were recruited through state birth registries from 15 states that recruited $62 \%$ of eligible cases in Phase 1. Controls were frequency matched to cases based on year of birth and region of residence and were required to have an English or Spanish speaking mother available for interview.

Data collection included maternal interview to collect demographic information, exposure history during pregnancy, and family history data. Demographic characteristics used in this analysis include maternal age at DNA collection (<30 years, $30-35$ years, $35-40$ years, > 40 years), maternal education ( $<$ high school, high school graduate, some college, college degree, advanced degree), race (white, other), and household income $(<\$ 20,000$, $\$ 20,000-\$ 50,000, \$ 50,000-\$ 75,000$, and $>\$ 75,000)$.

This study was approved by the institutional review board at the University of Minnesota. Informed consent was obtained from all participants.

\section{Hepatoblastoma study}

Cases and controls were recruited for the HB study as previously described [26]. Briefly, cases were eligible for the study if they were diagnosed with $\mathrm{HB}$ at a COG institution between January 2000 and December 2008 at age $\leq 6$ years. Additional eligibility criteria included birth in the United States and having an English- or Spanishspeaking birth mother available for interview.

Controls were recruited through rosters of randomly selected births provided by 32 state birth registries as described [27]. Controls were eligible for the study if they were born in the United States between 1994-2008 and if they had an English- or Spanish-speaking birth mother available for a telephone interview. Controls were frequency matched to cases on birthweight category $(<1500,1500-2500$, and $>2500 \mathrm{~g})$, sex, year of birth and geographic region of birth.

Data were collected from birth mothers of cases and controls by a standardized computer-assisted telephone interview. The interview included information on demographics, pregnancy history, maternal exposures, and family history of cancer. For this analysis, we evaluated the demographic variables listed above.

This study was approved by the institutional review board at the University of Minnesota and each participating COG institution. The study was also reviewed and approved by the state health departments that provided birth certificate data. Informed consent was obtained from all participants.

\section{DNA collection}

Buccal cell DNA was collected for mothers and children using mouthwash and cytobrush collection kits, respectively.
Two different types of cytobrushes were used for collection from children in both studies, including Epicentre Catch-All Sample Collection Swabs (QEC091H, Epicentre Biotechnologies, Madison, WI) and Cyto-Pak Cytosoft Brushes (Cat. \# CP-5B, Medical Packaging Corporation, Camarillo, CA). For the child's sample, mothers were instructed to firmly brush the inside of the child's cheek approximately 20 times with the swab and then to return the swab to the plastic container. The process was repeated on the other cheek with a separate swab.

Mouthwash collection kits were used to collect DNA from case and control mothers in both studies and a small subset of the older children in the HB study. Participants were mailed a small bottle of Scope mouthwash (Proctor and Gamble, Cincinnati, OH) and a sample collection jar. They were instructed to swish Scope vigorously in their mouth for 30-60 seconds prior to spitting into the sample collection container. This process was repeated until the Scope container was empty. The samples were then placed in a sealable plastic bag. All DNA samples were returned through the mail in a prepaid mailer.

\section{DNA storage and extraction}

Upon receipt in the laboratory, buccal brush DNA was stored at $4^{\circ} \mathrm{C}$ until DNA isolation. Mouthwash samples were stored at $-20^{\circ} \mathrm{C}$ until DNA isolation. DNA was extracted from buccal brushes, swabs, and mouthwash samples using the Puregene Buccal Cell DNA Isolation protocol (Gentra Systems, Minneapolis, MN) according to the manufacturer's protocol.

\section{DNA quantification}

DNA was quantified using Quantitative Real-Time PCR (qPCR). A standard curve from $0.01 \mathrm{ng}$ to $1000 \mathrm{ng}$ was generated using human genomic DNA (Promega Corporation, Madison, WI). The standards and extracted DNA were assayed in triplicate in a 96-well plate. The extracted DNA was diluted 10-fold before assaying. ABI Taqman RNase P Detection Reagent labeled with FAM and ABI Taqman Gene Expression Master Mix (Applied Biosystems Inc, Foster City, CA) were used to perform the assay. The plate was analyzed using the ABI PRISM 7900HT Sequence Detection System (Applied Biosystems Inc.). Results were accepted when the $\mathrm{R}^{2}$ value was greater than or equal to $98 \%$ with greater than $90 \%$ PCR efficiency and do not exceed a cycle threshold $(\mathrm{Ct})$ standard deviation of 0.25 .

\section{Statistical analysis}

All statistical analyses were conducted in SAS v.9.2 (SAS Institute, Cary, NC). The outcome variable (DNA yield) did not follow a normal distribution and thus was log_e transformed for all analyses. Following the transformation, 
the distribution was approximately normal. A two sample $t$-test with unequal variance was used to compare the yield of DNA in mothers and children in the two studies. Correlations between DNA yield in mothers and their children were evaluated using the Pearson correlation coefficient. Univariate and multivariable linear regression models were used to identify predictors of DNA yield. Variables that were included as potential predictors of DNA yield include: age (mother, child) at DNA collection, sex (for children), case-control status of child, buccal cell collection method (brush type or mouthwash), maternal education, maternal race, household income, DNA storage time in the laboratory, and season of DNA collection (Winter: DJF, Spring: MAM, Summer: JJA, Fall: SON). Analyses were conducted separately for children and mothers. Initial analyses were stratified by study population (HB or infant leukemia). Combined analyses of the two studies were also conducted with adjustment for study population. All reported $P$ values are two-sided.

\section{Competing interests}

The authors have no competing interests to disclose.

\section{Authors' contributions}

JNP, JAR, and LGS were responsible for conception, design, and implementation of the study. AJH, EL and CB conducted all laboratory assays for the manuscript. JNP was responsible for statistical analysis and writing the manuscript. All authors were responsible for reviewing and editing the manuscript. All authors have approved of the final submitted manuscript.

\section{Acknowledgments}

Financial support: This work was supported by the National Cancer Institute at the National Institutes of Health (R01 CA111355 to L.G.S., R01 CA079940 and K05 157439 to J.A.R.) and the Children's Cancer Research Fund, Minneapolis, MN.

\section{Author details}

${ }^{1}$ Division of Epidemiology and Clinical Research, Department of Pediatrics, University of Minnesota, Minneapolis, MN, USA. ${ }^{2}$ Masonic Cancer Center, University of Minnesota, Minneapolis, MN, USA. ${ }^{3}$ Department of Pediatrics, MMC 715, 420 Delaware St. S.E., Minneapolis, MN 55455, USA.

Received: 19 March 2013 Accepted: 3 August 2013

Published: 12 August 2013

\section{References}

1. Hansen TV, Simonsen MK, Nielsen FC, Hundrup YA: Collection of blood, saliva, and buccal cell samples in a pilot study on the Danish nurse cohort: comparison of the response rate and quality of genomic DNA. Cancer Epidemiol Biomarkers Prev 2007, 16(10):2072-2076.

2. Woo JG, Sun G, Haverbusch M, Indugula S, Martin LJ, Broderick JP, Deka R, Woo D: Quality assessment of buccal versus blood genomic DNA using the Affymetrix $500 \mathrm{~K}$ GeneChip. BMC Genet 2007, 8:79.

3. Feigelson HS, Rodriguez C, Welch R, Hutchinson A, Shao W, Jacobs K, Diver WR, Calle EE, Thun MJ, Hunter DJ, et al: Successful genome-wide scan in paired blood and buccal samples. Cancer Epidemiol Biomarkers Prev 2007, 16(5):1023-1025

4. Bahlo M, Stankovich J, Danoy P, Hickey PF, Taylor BV, Browning SR, Brown MA, Rubio JP: Saliva-derived DNA performs well in large-scale, high-density single-nucleotide polymorphism microarray studies. Cancer Epidemiol Biomarkers Prev 2010, 19(3):794-798.

5. Turnbull C, Perdeaux ER, Pernet D, Naranjo A, Renwick A, Seal S, Munoz-Xicola RM, Hanks S, Slade I, Zachariou A, et al: A genome-wide association study identifies susceptibility loci for Wilms tumor. Nat Genet 2012, 44(6):681-684.
6. Trevino LR, Yang W, French D, Hunger SP, Carroll WL, Devidas M, Willman C, Neale G, Downing J, Raimondi SC, et al: Germline genomic variants associated with childhood acute lymphoblastic leukemia. Nat Genet 2009, 41(9):1001-1005.

7. Zheng S, Ma X, Buffler PA, Smith MT, Wiencke JK: Whole genome amplification increases the efficiency and validity of buccal cell genotyping in pediatric populations. Cancer Epidemiol Biomarkers Prev 2001, 10(6):697-700.

8. Saftlas AF, Waldschmidt M, Logsden-Sackett N, Triche E, Field E: Optimizing buccal cell DNA yields in mothers and infants for human leukocyte antigen genotyping. Am J Epidemiol 2004, 160(1):77-84.

9. Torkos A, Teschner M, Erfurt P, Paasche G, Lenarz T, Stover T: The use of buccal smears for a non-invasive screening of the 35 delG mutation of the Connexin-26 gene in hearing impaired young children. Int J Pediatr Otorhinolaryngol 2006, 70(6):965-971.

10. Milne E, van Bockxmeer FM, Robertson L, Brisbane JM, Ashton LJ, Scott RJ, Armstrong BK: Buccal DNA collection: comparison of buccal swabs with FTA cards. Cancer Epidemiol Biomarkers Prev 2006, 15(4):816-819.

11. Beckett SM, Laughton SJ, Pozza LD, McCowage GB, Marshall G, Cohn RJ, Milne E, Ashton LJ: Buccal swabs and treated cards: methodological considerations for molecular epidemiologic studies examining pediatric populations. Am J Epidemio/ 2008, 167(10):1260-1267.

12. Garcia-Closas M, Egan KM, Abruzzo J, Newcomb PA, Titus-Ernstoff L, Franklin T, Bender PK, Beck JC, Le Marchand L, Lum A, et al: Collection of genomic DNA from adults in epidemiological studies by buccal cytobrush and mouthwash. Cancer Epidemiol Biomarkers Prev 2001, 10(6):687-696.

13. King IB, Satia-Abouta J, Thornquist MD, Bigler J, Patterson RE, Kristal AR, Shattuck AL, Potter JD, White E: Buccal cell DNA yield, quality, and collection costs: comparison of methods for large-scale studies. Cancer Epidemiol Biomarkers Prev 2002, 11(10 Pt 1):1130-1133.

14. Cozier YC, Palmer JR, Rosenberg L: Comparison of methods for collection of DNA samples by mail in the Black Women's health study. Ann Epidemiol 2004, 14(2):117-122.

15. Rogers NL, Cole SA, Lan HC, Crossa A, Demerath EW: New saliva DNA collection method compared to buccal cell collection techniques for epidemiological studies. Am J Hum Biol 2007, 19(3):319-326.

16. Lum A, Le Marchand L: A simple mouthwash method for obtaining genomic DNA in molecular epidemiological studies. Cancer Epidemiol Biomarkers Prev 1998, 7(8):719-724.

17. Heath EM, Morken NW, Campbell KA, Tkach D, Boyd EA, Strom DA: Use of buccal cells collected in mouthwash as a source of DNA for clinical testing. Arch Pathol Lab Med 2001, 125(1):127-133.

18. Feigelson HS, Rodriguez C, Robertson AS, Jacobs EJ, Calle EE, Reid YA, Thun MJ: Determinants of DNA yield and quality from buccal cell samples collected with mouthwash. Cancer Epidemiol Biomarkers Prev 2001, 10(9):1005-1008.

19. Gallagher ML, Sturchio C, Smith A, Koontz D, Jenkins MM, Honein MA, Rasmussen SA: Evaluation of mailed pediatric buccal cytobrushes for use in a case-control study of birth defects. Birth Defects Res A Clin Mol Teratol 2011, 91(7):642-648.

20. van Wieren-de Wijer DB, Maitland-van der Zee AH, de Boer A, Belitser SV Kroon AA, de Leeuw PW, Schiffers P, Janssen RG, van Duijn CM, Stricker BH, et al: Determinants of DNA yield and purity collected with buccal cell samples. Eur J Epidemiol 2009, 24(11):677-682.

21. Le Marchand L, Lum-Jones A, Saltzman B, Visaya V, Nomura AM, Kolonel LN: Feasibility of collecting buccal cell DNA by mail in a cohort study. Cancer Epidemiol Biomarkers Prev 2001, 10(6):701-703.

22. Ross JA, Linabery AM, Blommer CN, Langer EK, Spector LG, Hilden JM, Heerema NA, Radloff GA, Tower RL, Davies SM: Genetic variants modify susceptibility to leukemia in infants: a Children's Oncology Group report. Pediatr Blood Cancer 2013, 60(1):31-34.

23. Koni AC, Scott RA, Wang G, Bailey ME, Peplies J, Bammann K, Pitsiladis YP: DNA yield and quality of saliva samples and suitability for large-scale epidemiological studies in children. Int J Obes (Lond) 2011, 35(Suppl 1):S113-S118.

24. Puumala SE, Spector LG, Robison LL, Bunin GR, Olshan AF, Linabery AM, Roesler MA, Blair CK, Ross JA: Comparability and representativeness of control groups in a case-control study of infant leukemia: a report from the Children's Oncology Group. Am J Epidemiol 2009, 170(3):379-387.

25. Waksberg J: Sampling methods for random digit dialing. J Am Stat Assoc 1978, 73:40-46. 
26. Puumala SE, Ross JA, Feusner JH, Tomlinson GE, Malogolowkin MH, Krailo $M D$, Spector LG: Parental infertility, infertility treatment and hepatoblastoma: a report from the Children's Oncology Group. Hum Reprod 2012, 27(6):1649-1656.

27. Spector LG, Ross JA, Puumala SE, Roesler M, Olshan AF, Bunin GR: Feasibility of nationwide birth registry control selection in the United States. Am J Epidemiol 2007, 166(7):852-856.

doi:10.1186/1471-2156-14-69

Cite this article as: Poynter et al:: Predictors of mother and child DNA yields in buccal cell samples collected in pediatric cancer epidemiologic studies: a report from the Children's Oncology group. BMC Genetics 2013 14:69.

\section{Submit your next manuscript to BioMed Central and take full advantage of:}

- Convenient online submission

- Thorough peer review

- No space constraints or color figure charges

- Immediate publication on acceptance

- Inclusion in PubMed, CAS, Scopus and Google Scholar

- Research which is freely available for redistribution 